University of Nebraska - Lincoln

DigitalCommons@University of Nebraska - Lincoln

Faculty Publications from the Harold W. Manter Laboratory of Parasitology

$5-1965$

\title{
Cytogenetic Evidence for the Specific Distinction of an Alaskan Marmot, Marmota broweri Hall and Gilmore (Mammalia: Sciuridae)
}

\author{
Robert L. Rausch \\ Arctic Health Research Center, rausch@u.washington.edu \\ Virginia R. Rausch \\ Arctic Health Research Center
}

Follow this and additional works at: https://digitalcommons.unl.edu/parasitologyfacpubs

Part of the Parasitology Commons

Rausch, Robert L. and Rausch, Virginia R., "Cytogenetic Evidence for the Specific Distinction of an Alaskan Marmot, Marmota broweri Hall and Gilmore (Mammalia: Sciuridae)" (1965). Faculty Publications from the Harold W. Manter Laboratory of Parasitology. 538.

https://digitalcommons.unl.edu/parasitologyfacpubs/538

This Article is brought to you for free and open access by the Parasitology, Harold W. Manter Laboratory of at DigitalCommons@University of Nebraska - Lincoln. It has been accepted for inclusion in Faculty Publications from the Harold W. Manter Laboratory of Parasitology by an authorized administrator of DigitalCommons@University of Nebraska - Lincoln. 
From the Arctic Health Research Center, Public Health Service, U.S.Department of Health, Education, and Welfare, Anchorage, Alaska

\author{
CYTOGENETIC EVIDENCE \\ FOR THE SPECIFIC DISTINCTION OF AN ALASKAN MARYOT, \\ MARMOTA BROWERI HALL AND GILMORE \\ (MAMMALIA: SCIURIDAE) \\ By \\ Robert L. Rausch and Virginia R. Rausch \\ With 2 Figures in the Text \\ (Received December 7, 1964)
}

The marmot occurring in the Brooks Range of aretic Alaska is sufficiently similar morphologically to Marmota caligata (EschschoLTz) of northwestern North America, including central and southern Alaska, as to be considered a subspecies of the latter, designated $M$. caligata broweri HaLL and GILmore. We have found, however, that the two animals differ cytogenetically to a degree exceeding that usually observed in closely related, but distinct, species of Sciurids (NADLER, 1962: NADLER and BLOCK, 1962).

Most authorities recognize five North American species of giant ground squirrels of the genus Marmota Blumenbach. Three of these, M. caligata, M. olympus (Merriam), and M.vancouverensis Swarth, appear to be closely related (HoweLL, 1915; HALL and KELSON, 1959) and have been considered possibly to be conspecific with the Palaearctic M. marmota L. (ElLerman and MorRISON-SCOTt, 1951; RAUSCH, 1953). However, accumulating evidence indicates that the latter concept is erroneous. In 1953, one of us (RAUsch, 1953) suggested that acceptance of a more restricted definition of species of North American marmots belonging to the caligata-group would, on morphological grounds alone, necessitate a review of the taxonomic status of the marmot occurring in the Brooks Range. M. caligata broweri can now be distinguished at the specific level by morphological as well as by zoogeographic criteria; moreover, as reported herein, the results of a cytogenetic investigation demonstrate the specific distinction of M. c. broweri.

Cytological preparations were analyzed from 4 specimens of $M . c . c a l i g a t a$ from south-central Alaska (2 $\hat{o} \hat{o}$, Talkeetna Mountains; $1 \hat{\delta}$, Kenai Peninsula; $1 \hat{f}$ Chugach Mountains) and from 3 specimens of $M . c$. broweri from the central and eastern Brooks Range ( 1 f, Chandler Lake; 2 qq, Lake Peters). Chromosome numbers were also determined for M. olympus ( $1 \hat{\sigma}$, Olympic Peninsula, Washing. ton) and M.flaviventris (Audubon and Bachman) (1 ${ }_{+}$, Kamloops, British Columbia). 
Following the injection of Colcemide (Ciba Pharmaceutical Co.), the animals were killed and the cytological material was processed according to the method of NADLER and BLock (1962). Synthetic orcein used for staining was obtained from both G. T. Gurr Ltd., London, and Chroma Gesellschaft, Stuttgart. The preparations were made permanent by the freezing method of CoNGER and FArRCHTLD (1953).

Results of the counting of chromosomes in somatic cells (bone marrow) of $M . c$. caligata and $M . c$.broweri are summarized in the Table. It is concluded that the modal diploid number of $M$. c. caligata is 42 and that of $M . c$. broweri is 36 . Cells from the inactive testes also were studied, but few meiotic figures were present. Preparations also were made from spleen. In all cases, counts obtained were in agreement with those from bone marrow.

Table. Counts of chromosomes obtained from cells in bone marrow

\begin{tabular}{|c|c|c|c|c|c|c|c|c|c|c|c|c|c|c|c|}
\hline & 38 & 39 & $39 ?$ & & 40 & $40 ?$ & 41 & 41? & 42 & $42 ?$ & 43 & $43 ?$ & 44 & $44 ?$ & $45 ?$ \\
\hline 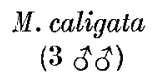 & 1 & 3 & 3 & & 5 & 2 & 7 & 4 & 38 & 6 & 3 & 3 & 1 & 1 & 1 \\
\hline \multirow{2}{*}{$\begin{array}{c}\text { M. caligata } \\
\left(\begin{array}{ll}1 & +\end{array}\right)\end{array}$} & - & 1 & 1 & & 1 & 1 & 3 & 2 & 11 & 4 & 1 & 2 & - & 1 & - \\
\hline & 33 & $33 ?$ & 34 & $34 ?$ & 35 & $35 ?$ & $\begin{array}{c}35 \\
?+1\end{array}$ & 36 & $36 ?$ & 37 & $37 ?$ & 38 & $38 ?$ & $39 ?$ & 40 ? \\
\hline $\begin{array}{c}\text { M. broweri } \\
\left(\begin{array}{ll}1 & \hat{\sigma}\end{array}\right)\end{array}$ & 3 & 1 & 1 & - & 4 & 3 & - & 40 & 3 & 4 & 4 & 2 & 1 & 1 & 1 \\
\hline $\begin{array}{c}\text { M. broweri } \\
\left(\begin{array}{l}2 \text { +9 }) \\
\text { (1) }\end{array}\right.\end{array}$ & 1 & 2 & 2 & 3 & 13 & 3 & 1 & 35 & 4 & 7 & 5 & 3 & 3 & - & 1 \\
\hline
\end{tabular}

Typical karyograms for $M . c$. caligata and $M$. c. broweri are illustrated in Figs. 1 and 2 . It is evident that the karyogram of $M$. c. caligata $(2 \mathrm{n}=42)$ differs strikingly from that of $M$. c. broweri $(2 \mathrm{n}=36)$ in both number and proportion of chromosomal types. Both have a large pair and a small pair of metacentric autosomes; $M$. c. caligata possesses 9 pairs each of submetacentric and acrocentric autosomes, while in $M$. c. broweri these number 12 and 3 pairs, respectively. The $\mathrm{X}$ chromosome of M.c. caligata is large and submetacentric; that of M.c.broweri is also large, but is metacentric or nearly so. The minute, dot-like $\mathrm{Y}$ chromosomes are quite similar in the two animals. We conclude that the Brooks Range marmot must be considered specifically distinct from $M$. caligata, the applicable name being $M$. broweri Hall and Gilmore.

Evidently only two of the Nearctic species of Marmola have the same number of chromosomes. From counts of cells from one animal, we concluded that $M$. flaviventris also has 42 chromosomes; we did 


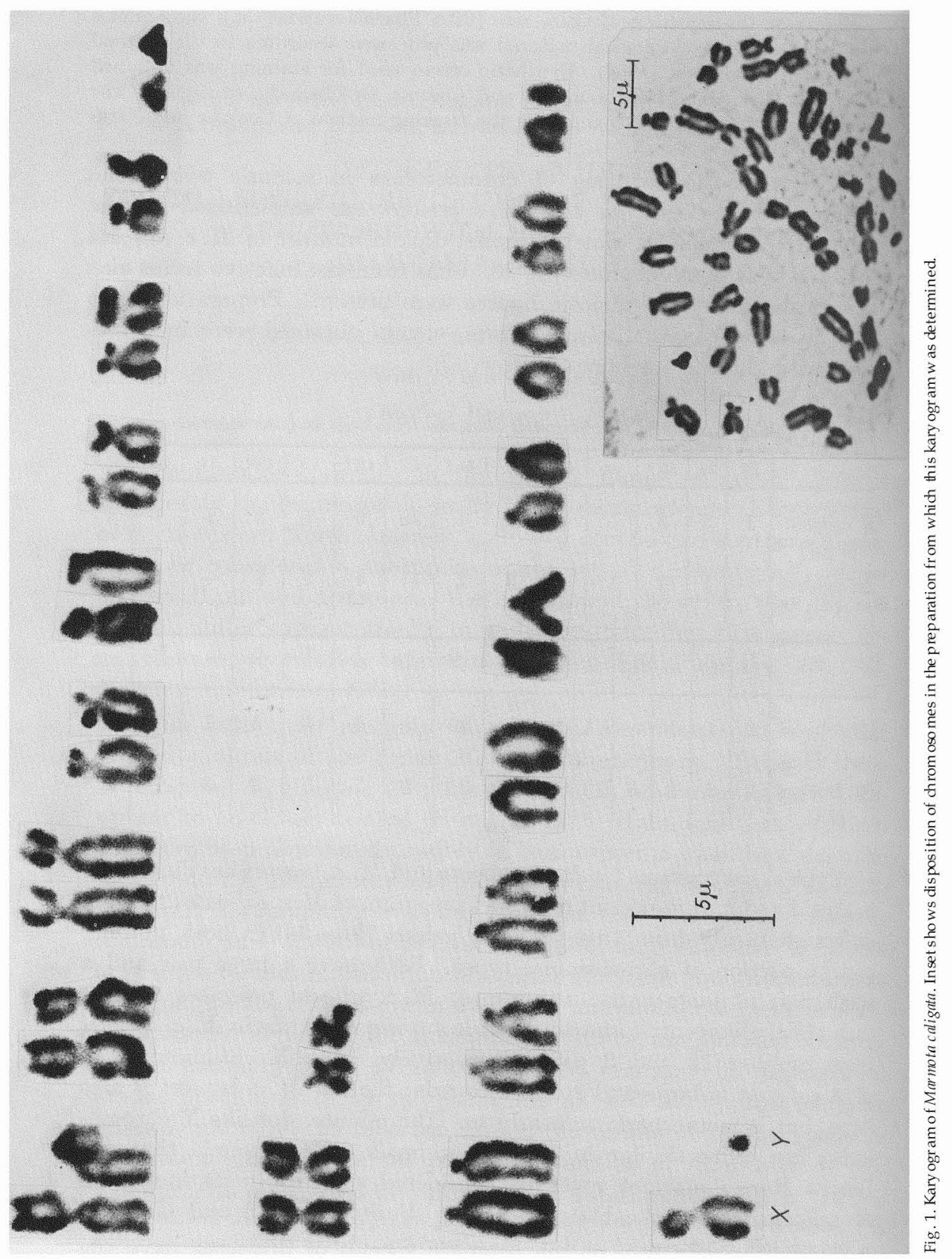

not, however, compare the karyogram of the latter species with that of $M$. caligata. It was determined that $M$. olympus has 40 chromosomes. 
This may be found to be the case with $M$. vancouverensis as well, since it is closely related to $M$. olympus, both species being regarded as preVashon (= pre-Wisconsin) relicts (DALQUEST, 1948), restricted in occurrence to alpine habitat on Vancouver Island and on the Olympic Peninsula, respectively. Further investigation may disclose that the two species are less closely related to $M$. caligata than previously supposed. In $M$. monax (Linnaeus), the number of chromosomes is smaller $(2 \mathrm{n}=38)$, and there are differences in proportions of chromosomal types (Couser et al., 1963).

Contingent upon the assumption that $M$. marmota is the dominant species of the subtribe Marmotina, Moone (1961) stated that "... it could be construed to have spread eastward successfully at least three times across the Bering land bridge, each time leaving an isolated population in the Nearctic Region which has speciated and survived." Three species, $M$. caligata, $M$. flaviventris, and $M$. monax, have extensive geographic ranges. The two occurring in Alaska, $M$. caligata and M. monax, seem clearly to be post-glacial invaders of northwestern North America, a conclusion supported by zoogeographic evidence and by the fact that certain parasites are not shared with Palaearctic species (RAUSCH, 1965, and unpublished). Evidence to be discussed elsewhere permits the inference that $M$. broweri survived the glaciations of Wisconsin time in the unglaciated Beringian region. Consequently, as suggested in 1959 by Dr. RoberT S. Hoffman, Montana State University, Missoula (personal communication), $M$. broweri may be closely related to, or even conspecific with, the eastern Sibcrian $M$. camtschatica Pallas, which itself may be a race of $M$. marmota (EtLerman and MorrisonScotT, 1951; Moore, 1961). Cytological data on M. camtschatica and I. marmota may well provide further evidence to support these hypotheses, and the results of the present study justify the expectation that cytotaxonomic investigations of other recognized Palaearetic species of Marmota will help clarify evolutionary relationships within this group of mammals.

\section{Summary}

Cytogenetic studies based upon somatic cells (bone marrow) have disclosed that the marmot hitherto designated Marmota caligata broweri HALL and GILMORE, occurring in the Brooks Range of arctic Alaska, differs from $M$. c. caligata (EschschoLTz) in number of chromosomes $(2 \mathrm{n}=36$ as compared with $2 \mathrm{n}=42$ in M. caligata) and in proportions of chromosomal types. Typical karyograms for the two species are presented. It is concluded that the Brooks Range marmot is specifically distinct from $M$. caligata, the applicable name being Marmota broweri HalL and GLmore. Also determined were diploid chromosome numbers 


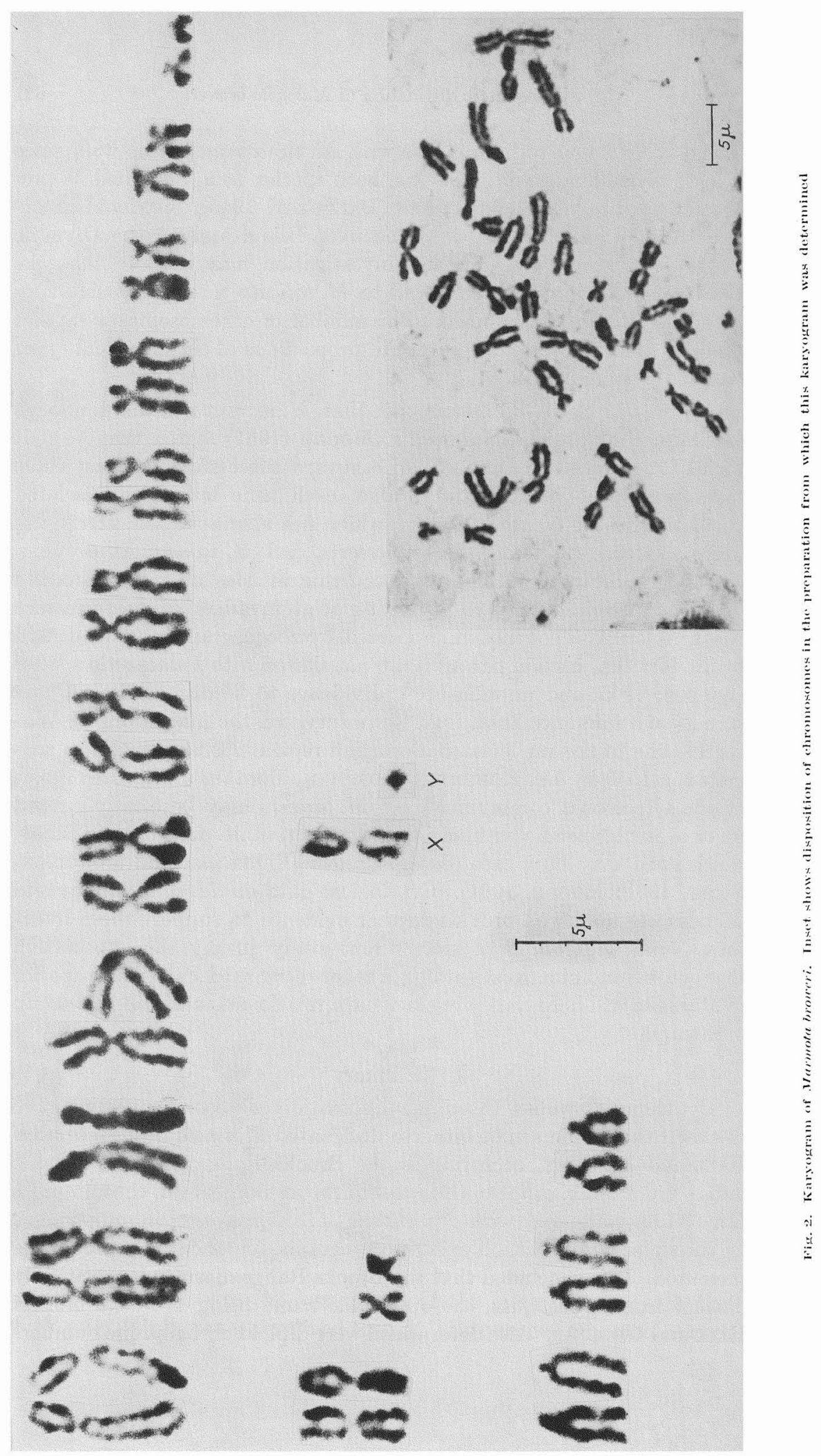


for two other Nearetic species of marmots, M. flaviventris (Audubon and BaChmax), with 42 , and M.olympus (Merriam), with 40 . It is suggested that $M$. broweri survived the last (Wisconsin) glaciations in the amphi-Beringian refugium, and that its closest affinities may be with one of the Eurasian species of Marmota.

Acknowledgements. We are indebted to Dr. Murray L. Johnson, College of Puget Sound, Tacoma, and Mr. JoHn D. Gregson, Entomology Division, Canada Department of Agriculture, Kamloops, for providing respectively the specimens of Olympic and yellow-bellied marmots, and to Mr. KENNETH L. Austerian, Aretic Health Research Center, for photographic assistance.

\section{Literature}

Cosger, A. D., and Lucile M. FairchiLd: A quick-freeze method for making smear slides permanent. Stain 'Technol, 28, 281-283 (1953).

Couser, W., P. Sargent, L. E. Brownhili, and K. Bentrschke: The somatic chromosomes of the Northeastern American woodchuck, Marmota monax. Cytologia (Tokyo) 28, 108-111 (1963).

Dalquest, W. W.: Mammals of Washington. Univ. Kansas Publ., Mus. Nat. Hist. $\mathbf{2 ,} 444$ p. (1948).

Ellekman, J. R., and T. C. S. Morrison-Scott: Checklist of Palaearctic and Indian Mammals 1758 to 1946,810 p. London, Brit. Mus. (Nat. Hist.) 1951.

HaLl, E. R., and K. R. Kelson: The Mammals of North America, vol. 1, 546 p. X. Y.: Ronald Press 1959.

How eld, A. H.: Revision of the American marmots. N. Amer. Fauna No 37, 80 p. (1915).

Moore, J. C.: The spread of existing diurnal squirrels across the Bering and Panamanian land bridges. Amer. Museum Novitates No 2044, 26 p. (1961).

NadLer, C. F.: Chromosome studies in certain subgenera of Spermophilus. Proc. Soc. exp. Biol. Med. (N.Y.) 110, 785-788 (1962).

-.., and M. H. BLock: The chromosomes of some North American chipmunks (Sciuridae) belonging to the genera Tamias and Eutamias. Chromosoma (Berl.) 13, $1-15(1962)$.

PuAsch, R. L.: On the status of some aretic mammals. Arctic 6, 91-148 (1953); Origin of the mammalian fauna of the Kodiak Archipelago. In: The Kodiak Island refugium, its geologic and biologic history. Ed. T. KarLstrom et al. (1965).

\section{Dr. R. L. Rausch}

Zoonotic Discase Section, Aretic Health Research Center $9456^{\text {th }}$ Avenue, Anchorage, Alaska 99501, USA 